\title{
Okul Öncesi Dönemdeki Çocuklara Eğitsel Oyunlar Yoluyla Kazandırılan Değerler ${ }^{1}$
}

DOI: $10.21666 /$ muefd.303856

\author{
Mevlüt Gündüz \\ Süleyman Demirel Üniversitesi, Eğitim Fakültesi, Temel Eğitim Bölümü,mevlutgunduz@sdu.edu.tr \\ Vedat Aktepe \\ Nevşehir Hacı Bektaşi Veli Üniversitesi, Eğitim Fakültesi, Temel Eğitim Bölümü, vedataktepe@nevsehir.edu.tr \\ Hamdenur Uzunoğlu \\ Milli Eğitim Bakanlığı, hamdenuruzunoglu@gmail.com \\ Dudu Duygu Gündüz \\ Süleyman Demirel Üniversitesi, Gönen Meslek Yüksek Okulu, dududuygugunduz@hotmail.com
}

\section{Özet}

Bu araştırmanın amacl, okul öncesi dönemdeki çocuklara eğitsel oyunlar oynatılarak onların ne gibi değerler kazandı̆̆ını ortaya çıkarmaktır. Araştırmada nitel araştırma yöntemlerinden eylem araştırması deseni kullanılmıştır. Araştırma, 2015-2016 öğretim yılında, Isparta iline bağlı Ĕgirdir ilçe merkezindeki devlet okulunda ögrrenim gören okul öncesi ögrencilerinden 23 ögrenciye her gün bir oyun olmak üzere toplamda 10 adet eğitsel oyunun oynatılması yoluyla gerçekleştirilmiştir. Araştırmada, örneklem belirlenirken amaçlı örneklem alma yöntemlerinden tipik durum örneklemi alma yoluna gidilmiştir. Katılımcılar cinsiyet, sosyoekonomik düzey, anne-baba ĕgitim seviyesi gibi durumlar açısından çeşitlilik göstermektedir. Araştırmada veriler, eğitsel oyunlar oynatıldıktan sonra her bir çocuk ile ayrı ayrı yapılan görüşmeler ve araştırmacılar tarafindan yapılan gözlemler yoluyla toplanmıştır. Toplanan nitel verilerin analizinde betimsel analiz yaklaşımı kullanılmıştır. Araştırmanın sonucunda; ĕgitsel oyunların çocuğun duygusal, sosyal, zihinsel ve bedensel yönlerini geliştirdiği gibi aynı

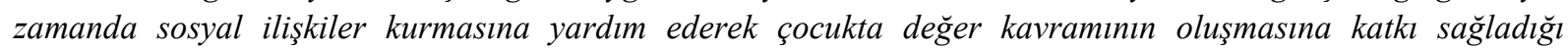
gözlemlenmiştir. Öğrencilerin oynadıkları oyunlar sayesinde saygl, nezaket, mutluluk, yardımseverlik, hoşgörü, sorumluluk, sabır, ait olma, duyarlılık, cesaret, adalet ve iyilik gibi değerleri kazandıklarl görülmüştür.

Anahtar Kelimeler: Ĕgitsel oyun, değer eğitimi, okul öncesi

\section{The Values Obtained through the Educative Games to PreSchool Children}

\begin{abstract}
The aim of this study is to find out what educational games play examples have obtained on pre-school children. In the research, action research is used in qualitative research methods. The research was carried out in the $2015-$ 2016 school year by playing a total of 10 educational games, 23 of which were students each day, from the preschool students in the state school in Eğirdir district of Isparta. In the study, sampling was used to get a typical case sample from the purposeful sampling methods. Participants vary in view of situations like sex, socialeconomic level and father-mother educational level. In research, data were gathered by the way of observation made by researchers and interviews made separetly with each child after the play of the educational games. A descriptive analysis approach was used in the analysis of the collected qualitative data.As a result of the research; It has been observed that educational games have helped the child develop emotional, social, intellectual and bodily aspects as well as contributing to the development of the concept of value in children by helping them to establish social relations at the same time. It has been seen that the students have acquired values such as respect, kindness, happiness, benevolence, tolerance, responsibility, patience, belonging, sensitivity, courage, justice and kindness through the plays they play.
\end{abstract}

Key words: Educational play, value education, preschool education

\footnotetext{
${ }^{1}$ Bu çalışma, 31 Mayıs - 03 Haziran 2016 tarihleri arasında Muğla Sıtkı Koçman Üniversitesi'nde düzenlenen III. Uluslararası Avrasya Eğitim Araştırmaları Kongresinde özet bildiri olarak sunulmuştur.
} 
Oyun; çocuklara yaparak yaşayarak öğrenme ortamları sunan, sosyal, duygusal, zihinsel ve fiziksel yönden gelişimini sağlayan, deneyim kazandıran, nesneleri kullanma, bedenini kontrol etme becerisi kazandırıp, hayal güçlerini geliştiren etkinliklerdir (Jones, 2001).

Çocukluk yaşamının her döneminde oyun, en önemli uğraşlardan biridir (Gelen \& Özer, 2010). Oyun bir çocuk için hiçbir zaman boş zaman etkinliği değildir. Çocuk oyuna sadece mutlu olmak veya oyalanmak için gereksinim duymaz. Oyun kişilik rollerinin provasının yapıldığı, yaşamın tecrübe edildiği bir etkinlik olarak görülmelidir. Bunun yanında, oyun çocuk için doğal bir eğlenme ve öğrenme ortamıdır. Çocukların karmaşık olayları, durumları, soyut kavramları anlamalarında en önemli araç olan oyunlar, onların yaratıcı düşünme ve duyuşsal alan becerilerinin gelişiminde de önemli bir etkiye sahiptir. Diğer yandan bir çocuk ancak oyun yoluyla kendini geliştirme imkânı bulur ve ilk deneyimlerini kazanır (Yıldırım,2012; Varışoğlu, Şeref, Gedik ve Yılmaz, 2013).

Oyun çağı olarak da bilinen 3-6 yaş dönemini kapsayan okul öncesi dönemde çocuklar, nesneleri ya da hayal ettikleri bir şeyi temsil etme yeteneğine sahiptir. Bu hayal gücü ilerideki yaşamına, insanlara, olaylara ve kendilerine olan bakış açılarına yön verir. Aynı zamanda oyun çocuğun çevreyle ilişki içinde olmasını (Maden, 2010) ve etrafindaki olaylardan haberdar olmasını sağlar (Sevinç, 2004). Oyun, içinde farklı kültürlerle karşılaşan çocuklar arasında kültür alışverişi gerçekleşir. Bu durum çocukların farklı yaşantıları görmesine olanak sağlar. Çocuklar arasında hoşgörülü davranma, farklı yaşantılara saygı duyma özellikleri gelişir (Hazar, 1996). Çocuk oyunlarının son derece sosyal olduğunu söyleyen Piaget, oyunu çocuklar için sosyal bir davranış şekli olarak belirtmekte ve sosyal becerilerin kazandırıldığı bir ortam olarak değerlendirmektedir (Pehlivan,2012:25).

Okul öncesi dönem, çocuğun gelişiminin artmaya başladığı yıllardır. Yapılan araştırmalarda çocukluk yıllarında kazanılan davranışlar, yetişkinlikte bireyin kişilik yapısını, tavır, alışkanlık, inanç ve değer yargılarını biçimlendirmektedir (Karaömerlioğlu, 2010; Tanrıverdi, 2012). Çocukların geleceğini belirleyecek olan toplumsal ve ahlaki değerlerin oluşması yaşamın ilk yıllarında başlar. Toplumsal değerlerin devamlılı̆̆ı sağlanması ve gelecek kuşaklara aktarılmasında okul öncesi eğitim temel yapı taşıdır. Çocukları tanımanın, onların dünyasını paylaşmanın birçok yolu vardır. Oyun, bu yolların en çok kullanılanıdır (Kadim, 2012).Ayrıca oyun esnasında bilinen pek çok toplumsal, sosyal ve kültürel davranışlar yanında daha farklı davranışlar kazandırılabilir. Çocuğa oyun esnasında; evdeki, okuldaki ve kendisine ait araç gereçleri özenle kullanması, onları koruması, düzeni bozmaması, tutumlu davranışlar göstermesi, çevreye, topluma yararlı olması ve zamanını verimli bir şekilde değerlendirmesi bilinci kazandırılabilir. Benzer şekilde oyun esnasında bireyin mensup olduğu ya da yaşadığı çevreye ait ahlaki ve vicdani değerler de öğretilebilir. Çocuğun bütün eylem ve isteklerinde toplumsal beklentileri de göz önünde bulundurması gerektiği düşüncesi oyunla kazandırılabilir

(Sevinç, 2004:18-19).

Çocuk yaşamının başlangıcından itibaren nasıl hareket edeceğini öğrenmeye başlar. Bu öğrenmeler gözlemleyerek, taklit ederek, deneme yanılmayla veya kavrayarak gerçekleşebilir. Öğrendiği bilgileri yaşama aktaran çocuk toplum kurallarına, örf ve adetlere ters düşmemeye özen gösterir. Böylece toplumsallaşmanın ilk adımı atılır. Bu noktada değerler eğitimi ortaya çıkar. Değer bir toplumda genel kabul gören veya benimsenen her türlü duygu, düşünce, davranış ve kurala denir (Bills ve Husbands, 2005).

Okul öncesi dönemindeki çocukların en sevdiği uğraşlardan olan etkinlikler, oyunlar, drama, tiyatrolar çocuğun hem eğlenmesini, hem mutlu olmasını hem de bazı değerleri kazanmasında önemli bir yere sahiptir. Öğretmenin bu uygulamaları yapması kendisi adına vazife, öğrenci içinse iyi karakterli bir kişilik, erdemli birey olması toplum içinde sosyal yaşama ayak uyduran, çevresince kabul edilen bir 
birey olması açısından çok önemlidir (Diana, 2010). O dönemdeki çocuklar karakter eğitimi açısından şekil vermeye müsaittirler. Bu durum çocuğun ileriki hayatına yön verecek bazı değerleri oyunla birleştirerek verilmesi açısından uygun bir dönemdir. Her ne kadar resmi programla bazı değerler kazandırılmaya çalışılsa da informal öğrenmelerin diğer bir deyişle örtük programın değerlerin kazandırılmasındaki önemi yadsınamaz (Doğanay, 2006; Illich, 2000; Tuncel, 2008; Türedi, 2008). Hatta bazı durumlarda resmi programdan daha etkili olduğu görülmektedir.

Çocuk için önemli bir yeri olan eğitsel oyunların informal öğrenmeler oluşturma açısından da uygun bir zemin olacaktır. Çünkü çocuk oyun oynarken farklı kişilerle etkileşime girecek ve doğaçlama yollarla bazı kazanımlara ulaşacaktır. Oyun, doğası gereği içinde sürpriz gelişmelere açık olmakla beraber aynı zamanda saygı ve hoşgörü duygularını geliştiren bir etkinliktir. İçinde bu tarz gizemleri bulunduran eğitsel oyunlar çocuklara bazı değerleri kazandırmak için kullanılabilir. Nitekim çocuk hem eğlenecek hem de farkında olmadan bazı değerleri kazanmış olacaktır.

Özetle oyunlar; çocukların bedensel, zihinsel ve psikolojik gelişimine olumlu katkı sağlayan, güven kazanma, işbirliği halinde olma, gruba ait olma, olumlu bağl1lı geliştiren etkinliklerdir. Aynı zamanda bireylerin çevreye duyarlılığını, dinlemeyi öğrenmeyi, saygı duymayı, kendi çıkarlarını geri plana atarak hoşgörülü olmayı öğreten ve geliştiren etkinliklerdir (Kara, 2010).

$\mathrm{Bu}$ gibi nedenlerden ötürü araştırmanın amacı, okul öncesi dönemdeki çocuklara eğitsel oyunlar oynatılarak onların ne gibi değerler kazandığını ortaya çıkarmaktır. Böylelikle de eğitsel oyunların, çocuğa eğitsel ve akademik anlamda farkındalık duygusu kazandırarak daha faydalı bir hale getirilebileceği düşünülmektedir. Bu yönüyle eğitsel oyunlar üzerine yapılan çalışmalardan farklılık arz etmektedir.

\section{Araştırma Deseni}

\section{Yöntem}

$\mathrm{Bu}$ araştırmada nitel araştırma desenlerinden eylem araştırması kullanılmıştır. Eylem araştırması, uygulama yapan kişinin kendisinin ya da bir araştırmacı ile birlikte gerçekleştirdiği ve uygulama süreciyle ilgili sorunları çözmek için kullanılan bir araştırma yaklaşımıdır (Beyhan, 2013; Sagor, 2004). Eylem araştırmaları öğretmen ve uzman araştırmacılar yürütücülüğünde, uygulayıcıların ve probleme taraf olanların da katılmasıyla, var olan uygulamanın eleştirel bir değerlendirilmesini yaparak, durumu iyileştirmek için alınması gereken önlemleri belirlemeyi amaçlayan araştırmalardır (Karasar, 1999:27). $\mathrm{Bu}$ çalışmaya da araştırmacı bizzat katıldığı ve yeri geldiğinde çeşitli yönlendirmeler yaptığı için eylem araştırması tercih edilmiştir.

\section{Çalışma Grubu}

$\mathrm{Bu}$ araştırma, 2015-2016 öğretim y1lında, Isparta iline bağlı Eğirdir ilçe merkezindeki bir devlet okulunda öğrenim gören 6 yaş grubundaki 23 okul öncesi öğrencisiyle (10 erkek, 13 kız) yapılmıştır. 23 ögrenciden hepsi daha önceden okul öncesi veya kreş eğitimi almıştır. Sosyo ekonomik durumları ve ebeveyn eğitim düzeyleri açısından da benzer yapıdadırlar.

Araştırma, her gün bir oyun olmak üzere toplamda 10 adet eğitsel oyunun oynatılması yoluyla gerçekleştirilmiştir. Öğrencilere oynatılan eğitsel oyunlar şunlardır: Üç küçük kuzu, sincap ve ceviz, uykucu horoz, meyve sepeti, hayvan müzesi, ördek nerede? ,eski minder, kör ressam, trafik ışıkları ve mikrop'tur. Bu oyunlar içerik açısından incelenmiş ve çoğu değeri bünyesinde barındırdığına karar verilmiştir.

Araştırmada, çalışma grubu belirlenirken amaçlı örneklem alma yöntemlerinden tipik durum örneklemi alma yoluna gidilmiştir. Derinlemesine araştırma yapabilmek amacıyla çalışmanın amacı bağlamında 
bilgi açısından zengin durumları seçebilmek için bu örneklem kullanılmıştır (Büyüköztürk, Çakmak, Akgün, Karadeniz ve Demirel, 2010). Tipik durum örneklemesi çalışma grubunu yansıtacak ortalama bir okul anlamına gelmektedir. Katılımcılar cinsiyet, sosyo-ekonomik düzey, anne-baba eğitim seviyesi gibi durumlar açısından çeşitlilik göstermektedir.

\section{Verilerin Toplanması ve Analizi}

Araştırmada veriler, eğitsel oyunlar oynatıldıktan sonra her bir çocuk ile ayrı ayrı yapılan görüşmeler ve araştırmacılar tarafindan yapılan gözlemler yoluyla toplanmıştır. Görüşme sırasında öğrencilere gerektiğinde ek sorularla yarı yapılandırılmış görüşme sağlanmıştır. Yarı yapılandırılmış görüşme tekniği sahip olduğu belirli düzeyde standartlık ve aynı zamanda esneklik nedeni ile eğitim bilim araştırmalarında daha uygun bir teknik görünümü vermektedir. Bu teknikte, araştırmacılar önceden sormayı planladığı soruları içeren görüşme protokolünü hazırlamıştır. Soruların her biri farklı verileri elde etmek üzere hazırlanmıştır. Görüşme soruları literatür taramasından sonra uzman görüşü alınarak düzenlenmiştir. Uzmanlar okul öncesi eğitimi ve değer eğitimi alanında çalışan öğretim üyelerinden oluşmaktadır.

Görüşme için hazırlanan 9 soru, uzman düzeltmeleri sonucu altıya indirilmiş ve içerik geçerliliği sağlanmıştır. Daha sonra katılımcılara uygulanan görüşme formlarına 1'den 23'e kadar numara verilerek bulguların daha kolay yorumlanması amaçlanmıştır. Bu görüşmeler ortalama 15-20 dakika sürmüştür. Öğrenciler okul öncesi öğretim döneminde olduğu için çalışmayla ilgili gerekli açıklamalar, öğrencilere detaylı bir şekilde yapılmıştır. Yarı yapılandırılmış görüşme için öğrencilere yöneltilen sorular şu şekildedir:

1- Bu oyunda neleri öğrendin?

2- Arkadaşlarına nasıl davrandın?

3- Arkadaşların sana nasıl davrandı?

4- Bundan sonra oyun oynarken nelere dikkat edeceksin?

5- Oyunun faydaları nelerdir?

6- Oyun oynarken nelere dikkat edilmesini istersin?

Toplanan nitel verilerin analizinde betimsel analiz yaklaşımı kullanılmıştır. Betimsel analizde, görüşülen öğrencilerin görüşlerini çarpıcı bir biçimde yansıtmak amacıyla doğrudan alıntılara çok defa yer verilmiştir. Betimsel analiz yapılmasındaki amaç, elde edilen bulguları düzenleyerek yorumlamak ve anlam bütünlügü içinde okuyucuya sunmaktır. Bu amaçla elde edilen veriler, önce mantıklı ve anlaş1lır bir biçimde betimlenmiş, daha sonra bu betimlemeler yorumlanmıştır. Yıldırım ve Şimşek'in (2005) ifade ettikleri gibi betimsel analiz dört adımda gerçekleştirilmiştir: Araştırma sorularından ve görüşme ve/veya gözlemde yer alan boyutlardan yola çıkarak veri analizi için bir çerçeve oluşturulması, bu çerçeveye göre verilerin işlenmesi ve sonuçlar yazılırken kullanılacak doğrudan alıntıların seçilmesi, bulgular ve organize edilmiş verilerin tanımlanması ve gerekli yerlerde doğrudan alıntılarla desteklenmesi, son olarak da bulguların yorumlanması ve bulgular arasında neden - sonuç ilişkilerinin açıklanması şeklindedir.

Araştırmanın güvenirliğini sağlamak amacıyla ise 3 uzman görüşüne başvurulmuştur. Araştırmanın güvenirliği Miles ve Huberman'ın (1994) formülü (Güvenirlik = görüş birliği / görüş birliği + görüş ayrılığı) kullanılarak hesaplanmıştır. Nitel çalışmalarda, uzman ve araştırmacı değerlendirmeleri arasındaki uyumun $\% 90$ ve üzeri olduğu durumlarda arzu edilen düzeyde bir güvenilirlik sağlanmış olmaktadır. Bu araştırmaya özgü olarak gerçekleştirilen güvenirlik çalışmasında \%91 oranında bir uzlaşma (güvenirlik) sağlanmıştır. Geçerlilik anlamında ise, toplanan verilerin ayrıntılı olarak betimlenmesi ve araştırmacının sonuçlara nasıl ulaştığını açıklaması geçerliğin önemli ölçütleri arasında yer alır (Yıldırım ve Şimşek, 2005). 


\section{Bulgular ve Yorumlar}

Okul öncesi dönemdeki çocuklara araştırmacılar tarafından 10 adet eğitsel oyun oynatılarak bazı değerleri kazandırmak amacıyla yapılan bu çalışmada, çocuklarla yapılan bire bir görüşmeler ve araştırmacılar tarafindan yapılan gözlemler sonucunda şu bulgulara ulaşılmıştır:

Tablo.1: Eğitsel oyunlarda kazanılan tüm değerler

\begin{tabular}{ll}
\hline Değerler & Frekans \\
\hline Sayg1 & 32 \\
\hline Nezaket & 16 \\
\hline Mutluluk & 9 \\
\hline Yardımseverlik & 7 \\
\hline Hoşgörü & 7 \\
\hline Sorumluluk & 5 \\
\hline Sabır & 5 \\
\hline Ait olma & 3 \\
\hline Duyarlılık & 3 \\
\hline Cesaret & 3 \\
\hline Adalet & 2 \\
\hline Şükretmek & 2 \\
\hline Liderlik & 1 \\
\hline İyilik & 1 \\
\hline Güler yüzlülük & 1 \\
\hline Dürüstlük & 1
\end{tabular}

Yukarıdaki Tablo 1'deki veriler analiz edildiğinde, çocukların oyun oynadıktan sonra söyledikleri cümleler ve yapılan gözlemler sonucunda en çok saygı $(n=32)$ ve nezaket $(n=16)$ değerlerini kazandıkları görülmektedir. Yine çocuklarla yapılan görüşmeler ve gözlemler sonucunda çocukların yardımseverlik, mutluluk, sabır, sorumluluk, duyarlılık, cesaret, liderlik, gruba ait olma, şükür, iyilik, dürüstlük, adalet ve hoşgörü gibi değerleri kazandıkları görülmüsşür.

Çocukların oyun oynarken kurallara uymada son derece istekli oldukları ve hatta uymayan arkadaşlarını uyardıkları görülmüştür. Oyun esnasında bütün öğrencilerin eğlenmeleri ve mutlu olmalarının yanında, sürekli olarak tekrar tekrar oyun oynama isteğine sahip oldukları tespit edilmiştir. Yapılan görüşmelerde, öğrenciler de çok eğlendiklerini, kurallara uyduklarını ve mutlu olduklarını belirtmişlerdir. Bunun yanında çocuklar, koşarken arkadaşlarına çarpmamayı, beklerken sabırlı olmayı, bir arkadaşı yanlış bir şey yaptığında hemen ona yardımcı olmayı ve ona nazik davranmayı, yaptıkları hataları bir daha yapmamayı, birinci olan arkadaşlarını alkışlamayı öğrendiklerini dile getirmişlerdir. Nitekim bu hususlar eğitsel oyunu değerlerle bir araya getiren bileşenlerdir.

Çocukların "arkadaşımla çarpıştığımda özür diledim” ifadesinde nezaket, "arkadaşlarımın başlarına yavaşça dokundum, vurmadım" ifadesinde $\operatorname{saygl,~"bu~oyunu~oynarken~çok~güldüm,~çünkü~çok~komikti"~}$ ifadesinde mutluluk, "gözleri görmeyen arkadaşlarıma oyunda yardımcı oldum" ifadesinde yardımseverlik, "aceleci olmamaya dikkat ettim" ifadesinde sabır, "trafik kurallarını öğrendim. Büyüdüğümde de kurallara uyacağım" ifadesinde sorumluluk, "arkadaşlarıma hiç zarar vermedim" ifadesinde duyarlılık değerini kazandıklarına dair ifadelere yer verdikleri görülmüştür. İnsanın kişiliğinin temelinin çocukluk yıllarında atıldığı göz önüne bulundurulursa, çocukların eğitsel oyunlar yoluyla bu değerleri okul öncesi yaş döneminde kazanmaya başlaması oldukça önemlidir. 
Dağbaşı'na (2007) göre oyun içerisinde bireyler birbirlerine saygılı olmayı, sorumluluk sahibi olmayı, kurallara uymayı, yenilse bile bu yenilgiyi kabul etmeyi öğrenir. Bu şekilde birey karşısındaki hata yapsa bile karşısındaki kişiyi o şekilde kabul ederek hem hoşgörü hem de saygılı olma değerini kazanmış olur. Ayrıca oyun çocukların hayal dünyasını genişleterek yeni şeyler keşfetmesini sağlar. İyi kötü, doğru yanlış, gibi kavramları oyun esnasında görür, benimser ve ileriki yaşamında uygulayarak kişilik haline getirir.

Oyun esnasında arkadaşları ile oynayan çocuk "işbirliğini ve toplu yaşam için gerekli kuralları öğrenmektedir. Oyun yoluyla sosyalleşen, ben ve başkası kavramlarının bilincine varan çocuk, toplumsal rollerini oyun aracılığı ile kavramaktadır (Özdemir, 2006: 29). Oyun aracılığıyla kuralları öğrenen çocuk zamanla bu kuralları benimser ve oyun esnasında arkadaşlarıyla uyumlu olmayı ve birbirlerine saygılı olmayı öğrenirler. Böylece çocukta kurallara uymanın yanında; başkalarının haklarına saygı göstermeyi de kavrayarak değerler sınıfı oluşmaya başlar (Üzer, Gürkan ve Ramazanoğlu, 2006). Oyun içerisinde çocuk farklı kültürlerden ve farklı ortamlardan gelen arkadaşlarıyla da ilişki kurar. Bu sayede birbirleriyle hoşgörülü olmayı ve birbirlerinin kültürel değerlerine karşı saygılı olurlar. Çünkü oyunun devamlılığı buna bağlıdır (Hazar, 2006).

Öğrencilerin saygı değerini kazandığını gösteren bazı cümleler aynen şu şekildedir:

Ö1: Hayvan müzesi oyununu oynarken "Arkadaşlarıma çok güzel davrandım” ,

Ö2: Ördek Nerede oyununu oynarken "Arkadaşım düştüğ̈̈nde gülmedim "

Ö3: Eski Minder oyununda "Arkadaşlarıma kötü söz söylemedim “,

Ö4: Trafik Işıkları oyununda "Arkadaşlarıma vurmadım "

Ö5: Mikrop Oyununda "Arkadaşım oynarken mızıkçılık yapmadım"

Ö6: Kör Ressam oyununu oynarken "Arkadaşlarımın oyununu sessizce izledim "

Çocukların yukarıdaki cümleleri kullanmaları onların saygı değerini kazanmaya başladıklarını gösterir. $\mathrm{Bu}$ değeri kazanan öğrenci kendisinin farklı bir birey olduğunu karşısındaki bireyin de bireysel, sosyal ve kültürel farklılıkları zenginlik olarak kabul edip farklı özelliklere sahip olabileceğini anlamaya başlar. Nezaketli olmada saygıyı takip eden başka bir değerdir. Öğrenciler oyunları oynarken; birbirlerini kırmadan, incitmeden, bir şey isterken rica ederek konuşmaları, kaza meydana gelse bile özür dilemeleri bu değeri kazandıklarını gösterir. Çocuklar oyun yoluyla büyüklerine ve birbirlerine karşı saygılı olmayı, başkası konuşurken karşı tarafı sessizce dinlemesi gerektiğini, günaydın, iyi geceler, iyi akşamlar, afiyet olsun, özür dilerim gibi sözel ifadeleri, trafik kurallarına uymayı, sofra adabına uyma gibi sosyal kuralları ve değerleri de öğrenmektedirler (Karadağ ve Çalışkan, 2005).

Öğrencilerin nezaketli olma değerini kazandıklarını gösteren cümlelerden bazıları aynen şu şekildedir:

Ö1: Üç Küçük Kuzu oyununu oynarken, "İyi davrandım, yer kaparken onları hiç itmedim"

Ö2:Uykucu Horoz oyununda "Kötü söz söylememelerini isterim, kötü söz çok kötü bir şeydir"

Ö3:Ördek Nerede oyununda "Oyuncağın isterken verebilir misin lütfen"

Ö4:Eski Minder oyununda "Hata yaptı̆̆ımda özür diledim"

Ö5:Kör Ressam oyununda "Düştügüumde bana yardım eden arkadaşıma teşekkür ettim” Ö:Mikrop oyununda "Yanlışlıkla birini düşürürsem özür dileyip barıştım"

Diğer kazanılan önemli bir değerde mutluluk değeridir. Oyun çocukların en çok sevdikleri etkinlik olduğu için bu süreçte eğlenmeleri, zevk almaları, sıkılmamaları, kahkaha atarak oynamaları mutluluk duygusunu kazanmalarını sağlamıştır. Lazarus'a göre oyun, kendiliğinden ortaya çıkan, hedefi olmayan, mutluluk getiren bir aktivitedir (Aral, 2001)

Öğrencilerin mutluluk değerine sahip olduklarını gösteren bazı cümleleri aynen şu şekildedir: 
Ö1:Üç Küçük Kuzu oyununda "Oyun oynamayı seviyorum, hiç sıkılmıyorum”

Ö2:Sincap ve Ceviz oyununda "Oyun oynarken çok mutlu oldum"

Ö3:Uykucu Horoz oyununda "Bu oyunu oynarken çok güldüm, çünkü çok komikti"

Ö4:Meyve Sepeti oyununda "Oyun oynamazsam çok mutsuz olurum"

Ö5:Hayvan Müzesi oyununda "Oyunu ben kazandım gülen yüz kazandım çok mutlu oldum"

Ö6:Ördek Nerede oyununda "Oyun oynarken çok eğlendim"

Ö7:Mikrop oyununda "Arkadaşlarımla oyun oynarken çok mutlu oluyoruz"

\section{Sonuç ve Tartışma}

Araştırma okul öncesi dönemdeki çocuklara eğitsel oyunlar oynatılarak onların ne gibi değerler kazandığını araştırmak için yapılmıştır. Yapılan görüşme ve gözlemlerden elde edilen verilerin yorumlanmasıyla aşağıdaki sonuçlara ulaşılmıştır.

Eğitsel oyunlar yoluyla öğrenciler olumlu bağl1lık, yüz yüze etkileşim, iletişim ve sosyal becerilerinin gelişmesi, bireysel sorumluluk gibi değerleri kazanır. Ayrıca öğrencilerde özgüvenin gelişmesi, farklı düşüncelerin ve ilgi alanlarının ortaya çıkmasıyla birlikte liderlik becerilerinin de gelişmesini sağlanır.

Doğduğu andan itibaren kendini sosyal bir ortamın içinde bulan insanın yaşamını sürdürebilmesi için sadece fizyolojik ihtiyaçlarını karşılaması yeterli değildir. Bireyin kendini güvende hissetmesi, yaşadığı çevreye ait olması, mutlu olması ve toplumdaki yerini alması için yaşamını paylaştığı insanlarla sosyal ilişkilerde de başarılı olması gereklidir.

Çocuğun sosyal ilişkilerde başarılı olması için birtakım görgü kuralları ve toplumsal değerleri kazanması gerekir. Okul öncesi dönemden itibaren sosyal becerilerin ve duygusal davranışların kazandırılmasında ise anne, baba ve öğretmene önemli görevler düşmektedir. Öğretmen ve ebeveynlerin işbirliği ile okul öncesi eğitimde çocuklarda; sırasını bekleme, kurallara uyma paylaşma, yardımlaşma, sorumluluk alma, arkadaşlık kurma, lider olma, kendine güven, hoşgörü, nazik olma ve iletişim gibi davranışları kazanması desteklenebilir. $\mathrm{Bu}$ davranışlar, öncelikle farklı etkinlikler ve eğitim yöntemleriyle kazandirılabilir (Ceylan, 2009)

Çocuğun, duygusal ve sosyal gelişiminde oyunun etkisi bilinen bir olgudur. Oyun, çocuğun ilgisini arttırır ve çocuğun hayal dünyasını zenginleştirerek yaratıcı fikirler bulmasına yardımcı olur. Ayrıca doğru-yanlış, güzel-çirkin, iyi-kötü, haklı-haksız gibi kavramları çocuk oyun sırasında görür, dener ve kendi fikriyle çatışmıyorsa onu benimseyerek kendisinin bir parçası yapar. Kendine uymuyorsa yinelemez ve öğrenmez. Yani oyun, çocuğun duygusal, sosyal, zihinsel ve bedensel yönlerini geliştirir. Öğretmen ve akranlarıyla sağlıklı sosyal ilişkiler kurmasına yardım eder (Çoban ve Nacar, 2006).

Sosyalleşme, doğumdan sonra başlayan bir süreçtir ve çocuklar okul öncesi eğitim dönemine gelinceye kadar birçok sosyal beceriyi ebeveynlerinden ve çevresindeki kişilerden öğrenirler. Çocuk ilk kez okul öncesi dönemde ev dışındaki insanlarla, özellikle kendi akranları ile nasıl birlikte olunacağını öğrenmeye başlar. Bu öğrenme, onun sosyal gelişimini sağlar ve yaşadığı topluma daha kolay uyum sağlamasına yardımcı olur. Okul öncesi eğitim, çocuklar için gerekli olan bilişsel, duyuşsal, psikomotor becerilerin gelişmesini ve sosyal uyarı ortamını sağlamaktadır (Arslan, 2009).

Okul öncesi çocukların sosyal gelişimlerini olumlu etkileyen faktörlerden biri olan arkadaş ilişkileri üç yaş civarında başlar. Bu yaşlarda arkadaş edinmek çocuklar için çok önemlidir. Yapılan araştırmalar sonucunda bu yaşlarda çocuk empati kuramaz fakat yine de başkalarının davranışlarını anlamaya ilgi duyar. Sosyal gelişim ilerleyen yaş ile birlikte hızlanmakta; çocuğun yaşadığ 1 deneyimlerin sayısı da artmakta ve bu sayede çocuk toplumca ve arkadaşlarınca kabul edilme, reddedilme deneyimlerini yaşamakta, bütün bunlar ilişkilerin başlatılabilmesi ve devamı için gerekli becerilerin kazanılmasını da sağlamaktadır (Palut, 2003).

Bireylerin topum tarafından kabul edilmesi için bazı sosyal becerilere sahip olması gereklidir. Sosyal beceriler, bir çocuğun çevresindeki diğer kişilere yönelik davranışlarını ve çevreye uyumunu kapsamaktadır. Sosyal becerilere sahip olan çocuklar; çevresindeki kişilerle ilişki kurmada, paylaşım yapmada, kurallara uymada, başkalarına ve çevresindeki diğer varlıklara duyarlı olmada, gerektiği 
zaman olumsuz duygularını kontrol altına almada oldukça başarılıdırlar. Bu çocuklar zaman ilerleyip yetişkin olduklarında ise, çevresindeki kişilerle sağlıklı ilişkiler kurabilirler, işbirliği ve hoşgörü içerisinde çalışabilirler, yaşamlarında mutlu ve başarılı olabilirler, başkalarının düşüncelerine ve duygularına saygı duyabilirler, kendisine gelen eleştirilere karşı hoşgörülüdürler ve başarısızlıkla karşılaşsalar bile yılmadan yoluna bakabilirler (Ceylan, 2009).

Sosyal becerileri akran ilişkilerinde gösteremeyen çocukların daha çok kendi isteklerini dayatmaya çalışma, paylaşmayı bilmeme, akranlarıyla uyum sorunu yaşayan, sosyal yönden pasif ve saldırgan hareketlerde bulundukları görülmüş; bunun sonucu olarak da akranları tarafindan dişlanma davranışlarını gördükleri, sosyal kabul edilebilirliğin görülmediği saptanmıştır. Olumlu akran ilişkileri çocukların kişilerarası yeterliliğini olumlu etkileyerek bireylerin sosyal çevrelerine uyumlarına ve kişilik özelliklerinin gelişmesine katkıda bulunabilir (Önder, 2005).

Sosyal kabul edilebilirliği yüksek olan çocuklar ise yaşıtlarıyla küçük gruplar halinde oynar. Bu sayede iletişim becerileri ve grup olma bilinci gelişir. Grup bilinci gelişmemiş çocuk başkalarını etkilemekten çok hoşlanır ve oyunda yaşıtlarını etkileme çabasına girdiği görülür. Fakat diğer çocuklarla oynamanın daha zevkli olduğunun farkına varan çocuk, bazı isteklerinin yapılması konusunda 1srar etmekten vazgeçer. Daha uyumlu ve kurallara uyan bir grup üyesi olmaya gayret eder (Şen, 2007).

Sonuç olarak bu araştırma göstermiştir ki eğitsel oyunların çocukların bazı değerleri daha erken yaşta kazanması ve hissetmesi açısından önemlidir. Değer eğitiminin temellerinin küçük yaşlarda başlaması gerektiği bilinen bir durumdur. Bu bağlamda çocuğa değerleri iyi telkin etmek için eğitsel oyunları bir firsat olarak kullanabiliriz.

\section{Kaynakça}

Aral, N. (2001). Okul Öncesi Eğitiminde Oyun. İstanbul: Ya Pa Ofset.

Arslan, A. (2009).Okul Öncesi Eğitimi Almış Ve Almamış İlköğretim İkinci Sınıf Öğrencilerinin Anlama Eğitimindeki Farklılıklar. Ekev Akademi, 13(40), 1-12.

Beyhan, A. (2013). Eğitim örgütlerinde eylem araştırması, Bilgisayar ve Eğitim Araştırmaları Dergisi, $1(2), 65-89$.

Bills, L., \& Husbands, C. (2005) Analysing 'Embedded Values' in History and Mathematics Classrooms. Paper presented at the Conference of the British Educational Research Association, 15-19 September, Manchester, England.

Büyüköztürk, Ş., Çakmak, E., Akgün, Ö. E., Karadeniz, Ş. ve Demirel, F. (2010). Bilimsel Araştırma Yöntemleri. (6.baskı). Ankara: Pegem Akademi Yayınevi.

Ceylan, Ş. (2009). Vıneland sosyal- duygusal erken çocukluk ölçeğinin geçerlik-güvenirlik çalışması ve okul öncesi eğitim kurumuna devam eden beş yaş çocuklarının sosyal-duygusal davranışlarına yaratıcı drama eğitiminin etkisinin incelenmesi. Yayınlanmış doktora tezi. Gazi Üniversitesi, Ankara

Çoban, B ve Nacar E. (2006). Okul Öncesi Eğitimde Ĕgitsel Oyunlar. Ankara: Nobel Basımevi

Dağbaşı, G. (2007). Oyun tekniği ve Arapça öğretiminde kullanımı. Yayımlanmamış Yüksek Lisans Tezi, Gazi Üniversitesi Eğitim Bilimleri Enstitüsü, Ankara.

Diana, N. P. R. (2010). The Advantages And Disadvantages Of Using Games In Teaching Vocabulary To The Third Graders Of Top School Elementary School. Final Project Report, Sebelas Maret University.

Doğanay, A. (2006). Değerler Ĕgitimi. Hayat Bilgisi ve Sosyal Bilgiler Öğretimi Yapılandırmacı Bir Yaklaşım. (Ed. C. Öztürk), Ankara: Pegem-A Yayıncılık.

Gelen, İ. ve B. Özer (2010). "Oyunlaştırmanın 5. Sınıf Matematik Dersinde Problem Çözme Becerisi ve Derse Karşı Tutum Üzerindeki Etkisi". e-journal of New World Sciences Academy, 5(1), 71-88.

Hazar, M. (2006). Beden Eğitimi ve Sporda Oyunla Eğitim. Ankara: Tutibay Limitet Şirketi Yayınları. 
Illıch, I. D. (2000). Okulsuz Toplum. (Çev. Mehmet ÖZAY). İstanbul: Şule Yayınları. Jones, M. (2001). Oyun ve Çocuk. Çev., Ayda Çayır. İstanbul: Kaknüs Yayıncılık.

Kadim, M. (2012). Okul Öncesi Öğretmenlerinin Oyun Öğretimine Yönelik Öz Yeterliklerinin İncelenmesi. Yayımlanmamış Yüksek Lisans Tezi. Abant İzzet Baysal Üniversitesi Eğitim Bilimleri Enstitüsü, Bolu.

Kara, M. (2010). Oyunlarla Yabancılara Türkçe Öğretimi, Türklük Bilimi Araştırmaları Dergisi, 15, 407-415

Karadağ, E. ve Çalışkan, N. (2005). Kuramdan uygulamaya ilköğretimde drama oyun ve işleniş örnekleriyle. Ankara: Anı Yayınc1l1k

Karaömerlioğlu, L. (2010). Okul Öncesi Eğitimde Doğaçlama. Yayımlanmamış Yüksek Lisans Tezi. Çukurova Üniversitesi Sosyal Bilimler Üniversitesi, Adana.

Karasar, N. (1999). Bilimsel Araştırma Yöntemi (9. Basım). Nobel Yayın Dağıtım. Ankara

Maden, S. (2010). "Türkçe Öğretmenlerinin Drama Yöntemlerini Kullanmaya Yönelik Öz

Yeterlikleri", Mustafa Kemal Üniversitesi Sosyal Bilimler Enstitüsü Dergisi, 14(7), 259-274.

Miles, M.B and Huberman, A.M. (1994). Qualitative dataanalysis,Thousand Oaks, CA: Sage. Önder, A. (2005). Okul öncesi dönemde akran ilişkileri. A. Oktay, ve Ö. P. Unutkan (Der.). Okul öncesi eğitimde güncel konular. (s. 249-265). İstanbul: Morpa Kültür Yayınları.

Özdemir, A. (2006). Sosyal Bilgiler Öğretiminde Oyun. Yayımlanmamış Yüksek Lisans Tezi, Gazi Üniversitesi Eğitim Bilimleri Enstitüsü, Ankara

Pehlivan, H. (2012). Oyun ve Öğrenme. (3. Bask1). Ankara: Anı Yayınc1l1k

Palut, B. (2003). "Sosyal Gelişim ve Arkadaşlık Ilişkileri". Erken Çocuklukta Gelişim ve Eğitimde Yeni Yaklaşımlar, (Yay. Haz. Müzeyyen Sevinç). İstanbul: Morpa Kültür Yayınları.

Sagor, R. (2004). The action research guidebook: A four-step process for educators and school teams. Thousand Oaks, CA: Sage.

Sevinç, M. (2004). Erken Çocukluk Gelişimi ve Eğitiminde Oyun. İstanbul:Yaylacık Matbaası Şen, S. (2007). Okul öncesi dönem çocuklarının temel özellikleri ve gereksinimleri. İçinde G. Haktanır (Ed.),

Okul öncesi eğitime giriş (s. 71-123). Ankara: Anı Yayıncılık.

Tanrıverdi, Ö. (2012). Yaratıcı Drama ile Verilen Eğitimin Okul Öncesi Öğrencilerin Çevre Farkındalığına Etkisi. Yüksek Lisans Tezi. Muğla Sıtkı Koçman Üniversitesi Eğitim Bilimleri Enstitüsü, Muğla.

Tuncel, İ. (2008). Duyuşsal özelliklerin gelişimi açısından örtük program, Yayımlanmamış Doktora Tezi, Hacettepe Üniversitesi, Sosyal Bilimler Enstitüsü, Ankara

Türedi, H. (2008). Örtük programın eğitimdeki önemi yeri, Yayımlanmamış yüksek lisans tezi, Sakarya Üniversitesi, Sosyal Bilimler Enstitüsü, Sakarya

Üzer, A. Gürkan, A.C ve Ramazanoğlu, M.O. (2006). Oyunun Çocuk Gelişimi Üzerine Etkisi.Doğu Anadolu Bölgesi Araştırmaları, 4(3), 54-57. http://web.firat.edu.tr/daum/default.asp?id=84, 20 Ekim 2016'de alınmıştır.

Varışoğlu, B., Şeref, İ., Gedik, M. ve Yılmaz, İ. (2013). Türkçe Dersinde Uygulanan Eğitsel Oyunlara Yönelik Tutum Ölçeği: Geçerlilik ve Güvenilirlik Çalışması. Adlyaman Üniversitesi Sosyal Bilimler Enstitüsü Dergisi Türkçenin Eğitimi Öğretimi Özel Sayısı, 6, 11, 1060-1081.

Yıldırım, A. ve Şimşek, H. (2005). Sosyal Bilimlerde Nitel Araştırma Yöntemler, Ankara: Seçkin Yayınlar1

Yıldırım, N. (2012). Yabancı Dil Öğretiminde Eğitsel Oyunlar Aracılı̆̆ıyla Mobil Öğrenme. Yayınlanmamış Yüksek Lisans Tezi, Fırat Üniversitesi, Elazı ̆̆. 